\title{
CD45RA-depleted Donor T-lymphocytes
}

National Cancer Institute

\section{Source}

National Cancer Institute. CD45RA-depleted Donor T-lymphocytes. NCI Thesaurus. Code C157369.

A preparation of donor lymphocytes that have been depleted of CD45RA-positive cells, that can potentially be used for immune reconstitution purposes. CD45RA depletion results in a cellular product that contains a high amount of memory $\mathrm{T}$-cells (T m). Upon infusion of the allogeneic CD45RA-depleted T-lymphocytes after a hematopoietic cell transplantation (HCT), these cells provide Tm recovery and are able to prevent viral infections. The depletion of the CD45RA-positive cells reduces the risk of graft-versushost disease (GvHD) upon infusion. CD45RA is expressed on naive T-cells, whereas Tm cells are CD45RA-negative. Naive T-cells have the potential to induce GvHD. 